Pendidikan Damai... Oleh: Yasin Nurfalah

\title{
PENDIDIKAN DAMAI ALTERNATIF PENDIDIKAN KORBAN KONFLIK KOMUNITAS SYI'AH SAMPANG MADURA
}

\author{
Oleh: \\ Yasin Nurfalah \\ yesnurfalah@gmail.com \\ Institut Agama Islam Tribakti (IAIT) Kediri
}

\section{Abstrak}

Pendidikan Damai Alternatif Pendidikan Korban Konflik (Studi Pendidikan Anak Komunitas Syiah Sampang Madura) penelitian ini hendak melihat konsep pendidikan damai yang sekarang menjadi kebutuhan di Indonesia. Akhir-akhir ini, Indonesia sering dilanda konflik sosial terutama konflik berbasis agama. Korban investasi masa depan adalah terhambatnya perkembangan anak-anak. Masa perkembangan mental maupun fisik harus terhambat trauma akibat konflik. Kejadian penyerangan terhadap komunitas Syiah di Sampang Madura merupakan potret konflik dengan korban anak-anak sangat banyak. Saat ini, terdapat sekitar 76 anak usia prasekolah dan sekolah dasar (PAUD/TK sejumlah 21 anak dan SD sejumlah 55 anak) yang tinggal bersama dengan orang tua mereka. Mereka adalah anak-anak yang secara psikologis mengalami trauma. Sebagaimana seluruh kisah orang yang hidup di pengungsian, hampir seluruh kehidupan berjalan dalam kondisi memprihatinkan. Pun dengan anak-anak pengungsi Syiah Sampang ini. Hak-hak hidupnya sebagai anak jelas tidak terpenuhi dengan baik. Di antara sekian banyak kehilangan, yang paling menyedihkan adalah hilangnya hak anak atas pendidikan Penelitian ini menggunakan penelitian kepustakaan (library research), yaitu penelitian yang kajiannya dilaksanakan dengan menelaah dan menelusuri berbagai literatur. Hasilya secara umum, hasil pendidikan damai anak-anak pengungsi Syiah Sampang Madura belum menunjukkan hasil maksimal. Pasalnya, kesadaran perlunya pendidikan 
kurang mendapat dukungan dari orang tua dan pemuka agama Syi'ah. Dari 76 anak pengungsi yang setiap hari hadir untuk mengikuti kegiatan pendidikan damai hanya 40-45. Hasil kajian ini, menurut peneliti perlu adanya pengembangan lebih mendalam tentang "pendidikan damai".

Kata Kunci: Pendidikan Damai Alternatif, Korban Konflik.

\section{Pendahuluan}

Salah satu tujuan pendidikan adalah mencetak karakter peserta didik berkepribadian kebangsaan. Dalam konteks Indonesia, karakter kebangsaan merujuk pada pengakuan tentang keberagamaan dengan menghilangkan pelbagai rasa yang mampu memecah belah persatuan. Hal ini menjadi tantangan dalam usaha mendidik anak-anak komunitas Syiah Sampang Madura yang mengungsi di Rumah Susun Jemundo Sidoarjo.

Sejak 2013, komunitas Syiah Sampang Madura mengungsi di Rumah Susun Jemundo Sidoarjo. Mereka diungsikan oleh Pemerintah Jawa Timur karena diusir oleh kelompok yang mengaku Sunni Madura. ${ }^{1}$ Alasannya, Syiah adalah ajaran yang sesat dan menyesatkan dan penduduk Madura tidak akan menerima ajaran Syi'ah. Akibat perlakukan tersebut anak-anak harus kehilangan masa-masa perkembangan anak. Ironisnya, mereka juga harus menerima stigma sebagai anak penganut aliran sesat (Syiah).

Seperti sudah jatuh tertimpa tangga. Ungkapan ini layaknya menggambarkan penderitaan anak-anak komunitas Syiah Sampang Madura. Penderitaan pertama, sebagai etnis Madura. Stigma yang diberikan masyarakat bahwa etnis Madura orang-orang yang berpendidikan rendah dan tidak bisa

1 CMARs, Potret Buram Jaminan Kebebasan Beragama dan Berkeyakinan di Jawa Timur (Surabaya: CMARS, 2013), h. 27. 
Pendidikan Damai... Oleh: Yasin Nurfalah

mengikuti aturan di luar komunitas suku Madura. Kedua sebagai anak penganut ajaran yang sesat dan menyesatkan. Kedua stigma inilah yang harus dipikul anak-anak komunitas Syiah Sampang Madura. dan berdampak terhadap peminggiran karena dianggap other. ${ }^{2}$

Dalam catatan konflik sosial berlatar belakang apapun, selalu anak menjadi korban paling terabaikan. Keberadan dan suara mereka tidak banyak didengarkan, karena dianggap sudah terwakili oleh orang tua. Padahal, beberapa riset menunjukkan, banyak anak korban konflik tidak pernah bisa pulih mental dan psikologinya. Akibatnya, anak-anak korban konflik sering menyendiri, dan trauma berhadapan dengan orang. Begitu pula kondisi anak pengungsi Syi' ah Sampang Madura yang berada di pengungsian Rumah Susun (rusun) Puspa Agro, Jemundo Sidoarjo.

Saat ini, terdapat sekitar 76 anak usia prasekolah dan sekolah dasar (PAUD/TK sejumlah 21 anak dan SD sejumlah 55 anak) yang tinggal bersama dengan orang tua mereka. Mereka adalah anak-anak yang secara psikologis mengalami trauma. Sebagaimana seluruh kisah orang yang hidup di pengungsian, hampir seluruh kehidupan berjalan dalam kondisi memprihatinkan. Pun dengan anak-anak pengungsi Syiah Sampang ini. Hak-hak hidupnya sebagai anak jelas tidak terpenuhi dengan baik.Di antara sekian banyak kehilangan, yang paling menyedihkan adalah hilangnya hak anak atas pendidikan. $^{3}$

Padahal, pasal 31 UUD 1945 mengamanatkan bahwa pendidikan merupakan hak bagi setiap warga negara dengan mengutamakan pendidikan dasar sebagai kewajiban warga

2 Afdillah Muhammad, Dari Panggung Dakwah Menuju Panggung Politik (Telaah Kritis Jaminan Hak KBB Komunits Syiah Sampang Madura) (Yogyakarta: UGM ), h, 45.

${ }^{3}$ A. Khoirul Mustamir, Dokumen Pengajuan Program Pendampingan Anak Pengungsi Syi'ah 2013 (Surabaya: CMARS, Gubeng Kertajaya), h. 2. Volume 30 Nomor 1 Januari-Juni 2019 
negara. Sebagaimana yang diungkapkan Daoed Joesoef tentang pentingnya suatu pendidikan, "Pendidikan merupakan segala bidang penghidupan, dalam memilih dan membina hidup yang baik, yang sesuai dengan martabat manusia". Dari pernyataan tersebut menyatakan bahwa pendidikan merupakan hal yang sangat penting dan tidak bisa lepas dari kehidupan. ${ }^{4}$

Hak atas pendidikan merupakan hak moral dan hak konstitusional. Ini sesuai dengan ketentuan UUD 1945 (pasca perubahan), khususnya Pasal 28 C Ayat (1) yang menyatakan, "Setiap orang berhak mengembangkan diri melalui pemenuhan kebutuhan dasarnya, berhak memperoleh pendidikan dan memperoleh manfaat dari ilmu pengetahuan dan teknologi, seni dan budaya, demi meningkatkan kualitas hidupnya dan demi kesejahteraan umat manusia". 5 Di tingkat internasional, Kovenan Internasional Hak ECOSOB yang telah diratifikasi Indonesia melalui UU No. 11 tahun 2005, tentang hak atas pendidikan Negara memiliki kewajiban untuk pendidikan dasar harus diwajibkan dan tersedia secara cumacuma bagi semua orang dalam keadaan dan kondisi apapun. ${ }^{6}$

Alasan terhambatnya pemenuhan kebutuhan pendidikan karena beban anggaran yang terlalu besar dalam pengeluaran Anggaran Pendapatan Belanja Daerah Jawa Timur dan alasan keamanan. Menurut pemerintah Jawa Timur, keberadaan mereka mendapat penolakan dari masyarakat. Karena itu, dikhawatirkan akan terjadi praktik-praktik diskriminasi terhadap mereka. Akibatnya, anak-anak komunitas Syiah Sampang Madura menikmati pendidikan yang disediakan pemerintah

${ }^{4}$ Harris, I. Conceptual Underpinnings of Peace Education," in: G. Salomon \& B. Nevo(Eds) Peace Education: The Concept, Principles, and Practices around The World, Lawrence Erlbaum (New York2000), terj. SN. Karikasari, dkk (Jakarta: Gramedia, 2001), h. 20.

${ }^{5}$ Undang-Undang Dasar (UUD) 1945 Amandemen 4

${ }^{6}$ Kovenan Ekonomi Sosial dan Budaya, Ratifikasi Undang-Undang No,. 11 tahun 2005. 
Jawa Timur dengan kualitas sangat minim. Menurut Ade, Direktur Akar Teki, penyediaan pendidikan di pengungsian tidak layak. Pasalnya, tidak mencerminkan suasana pendidikan sebagaimana suasana pendidikan-pendidikan normal. 76 anak hanya disediakan dua kelas, kelas atas dan kelas bawah. Kelas atas diperuntukkan anak-anak yang seharusnya kelas 4, 5 dan enam, sedangkan kelas bawah diperuntukkan anak-anak kelas 1, 2 dan 3.

Pembagian kelas tersebut karena dua alasan, pertama keterbatasan ruang rusun, yang sebagaian besar dijadikan tempat hunian dan kedua karena alasan kemampuan dasar rata-rata anak-anak. Keterbatasan ruang karena sebagian besar ruang digunakan untuk tempat hunian. setiap setengah atau satu tahun selalu ada jumlah pengungsi yang menikah dan menjadi keluarga sendiri. Hal ini tentu menuntut terpenuhinya hak mendapatkan tempat tinggal. Alasan kemampuan dasar rata-rata anak adalah kelas bawah yaitu kurang memahami membaca, menulis dan menghitung dengan baik. Sedangkan anak-anak kelas atas hanya mampu membaca ilmu-ilmu agama yang diberikan oleh pimpinan komunitas jamaah Syiah Sampang Madura. $^{7}$

Dalam konteks ini, CMARs menganalisis kebutuhan dasar anak lebih mendalam yaitu tentang kesadaran berbangsa dan bernegara. Selama ini, anak-anak tidak mendapatkan materi tentang kebangsaan. Di sisi lain, anak-anak juga tidak mendapatkan pendampingan khusus untuk menghilangkan trauma akibat kejadian penyerangan dan pengusian yang mereka alami. Dalam catatan CMARs, secara umum anak-anak masih trauma bertemu dengan orang-orang yang berpakaian ulama dan

${ }^{7}$ Ahmad Zainul Hamdi, "Titik Nol Jaminan Kebebasan Beraga dan Berkeyakinan (KBB) Bagi Jama'aSyiah Sampang Madura, Annual Report" (Surabaya: CMARs, 2014), Naskah Hasil Press Realese Laporan Tahunan LBH Surabaya, h 134. 
seragam polisi. Mereka menganggap bahwa dua atribut tersebut adalah orang-orang yang telah merebut masa-masa indah di kampung halaman, Sampang Madura.

Berdasarkan temuan-temuan di atas, CMARs dan Akar Teki membuat program "Sekolah Kabangsaan" untuk anak-anak kamunitas Syiah Sampang di pengungsian. Dengan pendekatan psikologi pembelajaran kedua lembaga tersebut momodifikasi Kurikulum Nasional (kurikulum 2013 dan kurikulum tematik) agar sesuai dengan anak-anak pengungsi yang dalam kategori anak-anak luar biasa atau berkebutuhan khusus. Strategi dan metode pembelajaran lebih banyak menggunakan lingkungan sekirar rumah susun.

Tujuan pembelajaran ada dua, yaitu, anak-anak mampu mengikuti materi-materi pendidikan sesuai dengan standar pendidikan nasional dan anak-anak bisa menghilangkan dendam dengan menumbuhkan kesadaran kebangsaan, bhineka tunggal $i k a$, pancasila dan perdamaian. Perlu dipahami, kebudayaan masyarakat Madura yang paling menonjol adalah warisan dendam akibat tergoresnya harga diri. Menurut Latif Wiyata, salah satu budaya turun temurun masyarakat Madura adalah Carok. ${ }^{8}$ Carok akan terus diwariskan selama dalam kegiatan carok dinilai tidak seimbang, curang dan masih menyisakan penghinaan terhadap harga diri orang Madura. Berangkat dari penjelasan inilah, penulis tertarik menulis implementasi konsep pendidikan kebangsaan dalam menghilangkan rasa dendam di anak-anak komunitas Syiah Sampang Madura.

Berdasarkan konteks penelitian di atas, maka peneliti fokus untuk mendalami: pertama, bagaimana konsep pendidikan damai, strategi dan metode pembelajaran yang disusun oleh CMARs dan Akar Teki dalam pembelajaran anak-anak

${ }^{8}$ Ahmad Zainul Hamdi, Pergeseran Islam Madura (Perjumpaan Islam Tradisional dan dan Islamisme di Bangkalan Madura Pasca Reformasi. (Surabaya: UINSA, 2015), h. 39. 
Komunitas Syi'ah Sampang Madura? Kedua, Bagaimana hasil penerapan konsep pendidikan damai, strategi dan metode pembelajaran yang disusun oleh CMARs dan Akar Teki dalam pembelajaran anak-anak Kmunitas Syi'ah Sampang Madura?

\section{Metode Penelitian}

Penelitian ini menggunakan penelitian kepustakaan (library research), yaitu penelitian yang kajiannya dilaksanakan dengan menelaah dan menelusuri berbagai literatur. ${ }^{9}$ Penelitian ini menyusun dan mencari data tentang penjelasan tentang kondisi pemenuhan hak pendidikan anak komunitas Syiah Sampang Madura yang berada di Jemundo Sidoarjo. Di sisi lain, peneliti menelaah konsep pendidikan kebangsaan yang selama ini di lakukan oleh Akar Teki dan Center for Marginalizzed Communities Studies (CMARs) Surabaya. Kedua lembaga ini merupakan lemabaga swadaya masyarakat yang mendampingi komunitas Syiah Sampang ini sejak 2009 dan sekarang konsen pada pendampingan anak-anak korban segala praktik marginalisasi

Di samping-sumber tersebut di atas, diambil sumber data sekunder dari buku-buku literatur atau karya tulis para pakar yang telah lebih dulu mengkaji permasalahan tersebut di atas (jika ditemukan) guna melengkapi data penelitian ini dan dapat dijadikan bahan perbandingan. Sedangkan sifat penelitian ini adalah penelitian deskriptif analisis. Konsep pendidikan kebangsaan sebagai langkah untuk mengagambarkan visi dan misi penyelenggaraan pendidikan anak-anak komunitas Syiah Sampang Madura.

Muhamad Nazir dalam hal ini menyatakan bahwa dalam penelitian kepustakaan, peneliti bertugas menggali teori-teori yang telah berkembang dalam bidang ilmu yang berkepentingan. 40.

${ }^{9}$ Nazir M, Metode Penelitian (Jakarta: Ghalia Indonesia, 1999), h. Volume 30 Nomor 1 Januari-Juni 2019 
Studi literatur, selain dari mencari sumber data sekunder yang akan mendukung penelitian, juga diperlukan untuk mengetahui sampai di mana ilmu yang berhubungan dengan penelitian telah berkembang, sampai di mana terdapat kesimpulan dan generalisasi yang telah pernah dibuat, sehingga situasi yang diperlukan dapat diperoleh. ${ }^{10}$

Selanjutnya Mestika Zed menjelaskan bahwa penelitian kepustakaan ialah serangkaian kegiatan yang berkenaan dengan metode pengumpulan data pustaka, membaca dan mencatat serta mengelolah bahan penelitian. Adapun ciri-ciri utama dalam penelitian kepustakan (Library Search) adalah sebagai berikut:

1. Peneliti berhadapan langsung dengan teks atau data angka dan bukan dengan pengetahuan langsung dari lapangan atau saksi mata berupa kejadian, orang atau benda lainya.

2. Data pustaka bersifat ",siap pakai", artinya peneliti tidak pergi kemana-mana, kecuali hanya berhadapan langsung dengan bahan sumber yang sudah tersedia di perpustakaan.

3. Data pustaka umumnya adalah sumber sekunder, dalam arti bahwa peneliti memperoleh bahan dan tangan kedua dan bukan data orisinil dari tangan pertama lapangan.

4. Kondisi data pustaka tidak dibatasi oleh ruang dan waktu. Peneliti berhadapan dengan informasi statik tetap. Artinya kapanpun ia datang dan pergi data tersebut tidak akan pernah berubah karena ia sudah merupakan data "mati" yang tersimpan dalam rekaman penulis. ${ }^{11}$

10 Muhadjir N, Metode Penelitian Kualitatif (Yogyakarta: Rake Sarasin), h.23.

11 Zed M, Metodologi Penelitian Kepustakaan ( Jakarta: Yayasan Obor Indonesia.2008), h. 45. 


\section{Pembahasan}

\section{Pendidikan Damai}

Secara umum, pengertian pendidikan damai menurut Ahmad Baedowi megutip pendapat Tricia S. Jones adalah " $a$ spectrum of processes that utilize communication skills and creative andanalytic thinking to prevent, manage, and peacefully resolve conflict". ${ }^{12}$ Perkembangan makna selanjutnya, istilah pendidikan damai di-breakdown kataperkata, yaitu kata 'pendidikan' dan 'damai'. Dua kata tersebut adalah konsep yang perlu dipahami untuk mengerti apa itu pendidikan damai. Dari pemahaman terhadap kedua konsep tersebut akan muncul sebuah konsep yang merupakan perpaduan dari konsep 'pendidikan' dan 'damai', yaitu pendidikan damai.

Sedangkan pendidikan merupakan suatu proses atau perbuatan khusus manusia sesuai dengan kodratnya. Allah SWT menciptakan manusia dalam bentuk bayi, makhluk tiada daya, berhadapan dengan manusia yang telah dewasa. Dalam konteks ini, sejatinya pendidikan merupakan usaha untuk menjembatani manusia yang memiliki kemampuan-kemampuan yang diperlukan untuk melangsungkan tugas hidupnya. Menurut Ngalim Purwanto adalah segala usaha orang dewasa dalam pergaulannya dengan anak-anak untuk memimpin perkembangan jasmani dan rohaninya ke arah kedewasaan. ${ }^{13}$ Menurut Ahmad D. Marimba, pendidikan adalah bimbingan atau pimpinan secara sadar oleh si pendidik terhadap perkembangan jasmani dan rohani si terdidik menuju terbentuknya kepribadian yang utama. ${ }^{14}$

12 Ahmad Baedowi, "Pendidikan Damai dan Resolusi Konflik untuk Sekolah," Media Indonesia,Senin, 1 Maret 2010, diunduh pada 24 Januari 2018 .

${ }^{13}$ Ngalim Purwanto, Ilmu Pendidikan Teoritis dan Praktis (Bandung: Remaja Rosdakarya,1995), h. 10.

14 Ahmad. D. Marimba, Pengantar Filsafat Pendidikan Islam (Bandung: al-Ma'arif, 1989), h. 23.

Volume 30 Nomor 1 Januari-Juni 2019 
Dalam pemahaman sederhana di atas, pendidikan dapat membantu manusia menjadi sosok yang memiliki nilai dengan eksistensinya yang dapat diakui dalam lingkungan masyarakat. Pendidikan menjadi sarana untuk memberikan tingkat kesamaan derajat tanpa membedakan suku, ras, agama atau golongan tertentu. Untuk itu, penekanan hasil pendidikan adalah perubahan perilaku dan sikap lebih baik. Dalam UndangUndang nomor 20 tahun 2003 tentang Sistem Pendidikan Nasional, pendidikan adalah usaha sadar untuk mewujudkan suasana belajar dan proses pembelajaran agar peserta didik secara aktif mengembangkan potensi dirinya untuk memiliki kekuatan spiritual keagamaan, pengendalian diri, kepribadian, kecerdasan, akhlak mulia, serta keterampilannya yang diperlukan dirinya, masyarakat bangsa dan negara. ${ }^{15}$

Dalam terminologi empirisme, Locke memperkenalkan teori "tabula rasa." Namun manusia diberi potensi kecerdasan, pendengaran, pengelihatan dan hati. Dalam konteks psikologis, penelitian Gardner dan rekan-rekannya di Harvard University telah menunjukkan "ada delapan potensi kecerdasan dalam diri manusia yang harus dikembangkan dengan baik, kecerdasan tersebut antara lain kecerdasan linguistik, kecerdasan matematis logis, kecerdasan spasial, kecerdasan kinestetik, kecerdasan musikal, kecerdasan antar pribadi, kecerdasan intrapribadi dan kecerdasan Naturalis". ${ }^{16}$

Dari beberapa pengertian menurut beberapa pakar pendidikan, maka penulis berinisiatif menyimpulkan bahwa pendidikan adalah segala usaha yang dilakukan baik untuk dirinya sendiri ataupun orang lain guna menuju kesempurnaan ayat 1 .

${ }^{15}$ UU No. 20 Tahun 2003 tentang Sistem Pendidikan Nasional, pasal 1

${ }^{16}$ Malik, Ichsan, "Kedamaian, Keadilan, Hak Asasi \& Penegakan Hukum (Semarang: IAIN Walisongo, 2008), h.30. 
sehingga mau dan mampu melaksanakan norma-norma kebenaran dan kebaikan.

Sedangkan makna damai, sebagai kata inti dari kedamaian, menurut Ichsan Malik dapat didefinisikan sebagai dihormatinya manusia dan kemanusiaan secara optimal akibat bekerjanya sistem sosial, ekonomi, politik, keamanan, dan pertahanan secara efektif, yang berujung kepada terwujudnya keadilan kepada semua pihak. Definisi ini bersifat menyeluruh, untuk membedakannya dengan damai yang cukup diartikan sebagai berakhirnya perang yang terjadi, atau berhentinya konflik kekerasan.

Reardon menegaskan bahwa damai adalah ketiadaan kekerasan dalam berbagai bentuk, apakah itu bentuk fisik, sosial, psikologis, maupun struktural. Bagi O'Kane pengertian Reardon adalah pengertian yang menyederhanakan masalah, terlalu pasif dan tidak responsif terhadap cara bagaimana berdamai dengan masa lalu. Damai dalam pengertian di atas juga dapat berpotensi menyebabkan pengabaian terhadap perasaan ketidakpercayaan dan kecurigaan yang dimiliki oleh orang-orang yang terlibat dalam konflik. ${ }^{17}$

Menurut Johan Galtung damai memiliki dua wajah. Pertama, damai yang negatif. Damai yang negatif adalah ketidakadaan perang atau kondisi tanpa konflik langsung (absent of conflict). Kondisi tanpa konflik ini bukanlah kondisi yang tercipta dengan sendirinya, namun membutuhkan prasyaratprasyarat agar konflik tidak terjadi, yaitu tidak adanya sebabsebab yang mendorong terjadinya konflik. ${ }^{18}$

${ }^{17}$ Johan Galtung, “A Mini Theory of Peace”, January 4, 2007, artikel online:

http://www.transnational.org/Resources_Treasures/2007/Galtung_MiniTheor y.html,diunduh tanggal 23 Januari 2019.

18 Simon Fisher et.al, Mengelola KonflikKeterampilan dan Strategi untuk Bertindak, terj. SN. Karikasari, dkk (Jakarta: Gramedia, 2001), h. 43. 
Damai negatif, di samping membutuhkan prasyarat tidak adanya sebab-sebab konflik, juga membutuhkan kontrol kekerasan yang dilakukan oleh pemerintah melalui pengamanan dan perlindungan. Strateginya adalah melalui pemisahan, sehingga pihak-pihak yang berkonflik tidak bertemu satu dengan lain. Model ini dapat dilakukan dalam situasi konflik baru terjadi, tetapi untuk jangka waktu lama sebaiknya tidak dilakukan. Wajah kedua dari perdamaian, menurut Galtung adalah damai positif (positive peace). Damai yang positif adalah suasana di mana terdapat kesejahteraan kebebasan, dan keadilan. Sebabnya, damai hanya dapat terjadi jika terdapat kesejahteraan, kebebasan, dan keadilan di dalam masyarakat. Tanpa itu tidak akan pernah terjadi kedamaian yang sesungguhnya di dalam masyarakat. ${ }^{19}$

Selain tipe damai negatif dan damai positif menurut Galtung, juga terdapat damai dingin (cold peace) dan damai panas (hot peace). Dalam damai dingin terdapat sedikit rasa kebencian di antara pihak-pihak yang bertikai tetapi juga kurangnya interaksi menguntungkan antarpihak yang dapat membangun kepercayaan, saling ketergantungan, dan kerjasama. Bagi damai panas, kerjasama aktif diperlukan untuk menjadi jembatan untuk memperbaiki masa lalu dan membangun masa depan. Hal ini membutuhkan titik temu (common ground) dan perhatian bersama terhadap masalahmasalah kemanusiaan yang dialami. Masalah-masalah kemanusiaan tersebut dapat berupa kemiskinan, hak asasi manusia, keterbelakangan pendidikan, persoalan kesehatan, diskriminasi, ketidakadilan, polusi tanah, air dan udara.

Gabriel Solomon, sebagaimana dikutip oleh H.B. Danesh menyimpulkan bahwa aktivitas pendidikan damai saat ini berada

19 Nizar, M, "Pendidikan Anak Korban Konflik," artikel online:http://pendidikanlayanankhusus.wordpress.com,13 Oktober 2014, diakses 23 Januari September 2018. 
dalam empat kategori: (1) pendidikan damai semata-mata sebagai 'aktivitas perubahan mindset'; (2) pendidikan damai semata-mata sebagai 'penanaman seperangkat kecakapan atau skill'; (3) pendidikan damai sebagai 'promosi hak asasi manusia (khususnya di negara-negara dunia ketiga)', dan (4) pendidikan damai sebagai aktivitas pengelolaan lingkungan hidup, pelucutan senjata dan promosi budaya damai. Di antara tujuan pendidikan damai, menurut Ian Harris, adalah:

to appreciate the richness of the concept of peace; to address fears; to provide information about security systems; to understand violent behaviour; to develop intercultural understanding; to provide for a future orientation; to teach peace as a process; to promote a concept of peace accompanied by social justice; to stimulate a respect for life; and to end violence,

Menurut Elise Boulding, pendidikan damai yang terus menerus akan menghasilkan budaya damai. Budaya damai ini pertama-tama dapat ditemukan di dalam lingkup rumah tangga. Ia mengatakan bahwa, bahwa orang tua, khususnya para ibu memiliki peranan strategis dalam rangka mendidik dan menumbuhkan budaya damai dalam keluarga.

The familial household is an important source of peace culture in any society. It is there that women's nurturing culture flourishes. Traditionally, women have been the farmers as well as the bearers and rearers of children, the feeders and healers of the extended family. The kind of responsiveness to growing things-plants, animals, babies - that women have had to learn for the human species to survive is central to the development of peaceful behavior.

Sebaliknya, keluarga dan rumah bisa menjadi sumber kekerasan dan pendidikan kekerasan bagi anggota-anggotanya. Penggunaan kekuasaan, khususnya dalam struktur keluarga yang 
patriarkis, terkadang menimbulkan kekerasan terhadap perempuan dan anak-anak. Anak-anak akan belajar dari orang tua mereka bagaimana menangani konflik, dan bagaimana mereka bersikap terhadap orang lain yang memiliki tampilan yang berbeda.

Menurut Ahmad Baedowi, untuk mengajarkan budaya damai di komunitas korban konflik, pengelola sebaiknya mempertimbangkan untuk memasukkan agenda keragaman budaya dan etnik dalam pengejarannya. Muatan keragaman budaya dan etnik juga difungsikan mengubah dan menambah respons pedagogis guru. Jika guru memiliki kepekaan budaya dan etnik yang kuat, respon pedagogis guru akan meningkat dengan sendirinya.

Geneva Gay dalam Culturally Responsive Teaching, sebagaimana dikutip Baedowi, memberikan sedikitnya tiga argumen mengapa muatan budaya dan etnik itu sangat strategis dan penting untuk ditubuhkan dalam pendidikan damai. Pertama, muatan budaya dan etnik dalam pendidikan damai sangat krusial sekaligus esensial bagi perbaikan aspek pedagogis pengajar dalam mengajar. Kedua, karena kebanyakan sumber belajar di ruang kelas adalah textbook, memasukkan agenda budaya dan etnik ke dalam textbook merupakan keniscayaan karena hal itu akan mengubah gaya mengajar guru. Ketiga, relevansi muatan budaya dan etnik dalam sekolah damai menyumbang kelestarian sejarah, budaya, dan tradisi sebuah etnis tertentu sehingga pada akhirnya dapat meningkatkan apresiasi kebangsaan yang tinggi dan memunculkan kohesivitas dan toleransi.

\section{Konflik}

Konflik merupakan antitesisnya perdamaian. Konflik bisa terjadi di mana saja, kapan saja, oleh siapa saja, dan dalam situasi apa saja. Di dalam buku Peace Education, Amy 
Ohlendorf, memberikan definisi tentang konflik yaitu hasil dari adanya perbedaan pandangan, penerimaan, dan nilai-nilai seseorang ataupun sekelompok orang. ${ }^{20}$ Dalam kondisi masyarakat yang homogen pun konflik dapat saja terjadi. Apalagi dalam sebuah entitas politik yang heterogen baik suku bangsa, agama, adat-istiadat, dan sebagainya, sudah tidak lazim jika konfik sering muncul.

Istilah "conflict" di dalam bahasa aslinya berarti suatu "perkelahian, peperangan, atau perjuangan", yaitu berupa konfrontasi fisik antara beberapa pihak. Arti kata konflik kemudian berkembang dengan masuknya "ketidaksepakatan yang tajam atau oposisi atas berbagai kepentingan, ide, dan lainlain". Istilah konflik saat ini juga menyentuh aspek psikologis di balik konfrontasi fisik yang terjadi. Istilah "conflict" menjadi begitu meluas sehingga beresiko kehilangan statusnya sebagai sebuah konsep tunggal. ${ }^{21}$

Pruitt dan Rubin mendefinisikan konflik adalah persepsi mengenai perbedaan kepentingan atau suatu kepercayaan bahwa aspirasi pihak-pihak yang berkonflik tidak dapat dicapai secara simultan. Konflik sosial dapat diartikan dalam dua hal, yakni yang pertama adalah perspektif atau sudut pandang tertentu di mana konflik dianggap selalu ada dan mewarnai segenap aspek interaksi manusia dan struktur sosial, sedangkan yang kedua adalah pertikaian yang terbuka seperti perang, revolusi, pemogokan dan gerakan perlawanan. ${ }^{22}$

Marx melihat masyarakat manusia sebagai sebuah proses perkembangan yang akan menyudahi konflik. Marx mengantisipasi bahwa kedamaian dan harmoni akan menjadi

${ }^{20}$ Zamroni, Peace Education, Volume I, II, dan III (Yogyakarta: Pascasarjana UNY, 2008)

${ }^{21}$ Dean G. Pruit dan Jeffrey Z. Rubin, Teori Konflik Sosial, terj. Helly P. Soetjipto, Cet. III (Yogyakarta: Pustaka Pelajar, 2011), h. 9.

22 Adam Kuper dan Jessica Kuper, Ensiklopedi Ilmu-ilmu Sosial, terj. Haris Munandar (Jakarta: RajaGrafindo Persada, 2000), h. 155-156. 
hasil akhir sejarah perang dan revolusi kekerasan. Bentrokan kepentingan-kepentingan ekonomis akan berakhir di dalam sebuah bentuk masyarakat tanpa kelas, bebas konflik dan kreatif. Penyebab ekonomis dari konflik sosial dan cara-cara konflik itu dibendung dan ditekan oleh kelas yang berkuasa di dalam setiap masyarakat sebelum meledak menjadi bentukbentuk kehidupan sosial yang baru. ${ }^{23}$

Setiap orang pun tidak luput mengalami konflik. Gary T. Furlong, dalam bukunya The Conflict Resolution Toolbox, mengatakan: kita semua dihadapkan pada situasi konflik di dalam banyak aspek kehidupan kita, apakah di kehidupan pribadi setiap orang, di dalam lingkungan kerja, atau dengan seseorang yang baru kita kenal sekalipun. Konflik yang ada bisa saja mengarah ke konflik yang sifatnya massal dengan menggunakan kekerasan fisik. Perlu langkah yang tepat bagi seseorang yang dihadapkan pada situasi konflik, agar konflik tidak melebar dan menjurus ke arah pertumpahan darah. Orang sekarang apalagi yang masih muda-muda sangat gampang sekali tersulut api kemarahan oleh masalah kecil/sepele yang seharusnya tidak sampai ke arah terjadinya konflik secara terbuka.

Menurut Amy Ohlendorf, dijelaskan tentang pengertian konflik yaitu suatu situasi persaingan yang di dalamnya orangorang sadar akan adanya ketidaksesuaian posisi potensial di masa depan dan masing-masing orang berniat untuk menguasai posisi yang dirasa tidak sesuai untuk yang lainnya. Konflik diibaratkan sebagai siklus: "Sama dengan proses sosial, ada sebabnya, ada prosesnya, yang mempunyai akibat atau dampaknya." 24

23 Tom Campbell, Tujuh Teori Sosial, Sketsa, Penilaian dan Perbandingan, terj. F. Budi Hadiman (Yogyakarta: Kanisius, 2001), h. 134.

24 Wulandari, "Taat: Menciptakan Perdamaian Melalui Pendidikan Perdamaian di Sekolah" (Artikel dari MOZAIK Volume. V No. 1 Januari 2015), h. 17. 
Dalam tulisan ini, konflik Sunni Syiah menjadi fokus penelitian. Fakta-fakta Sunni-Syi'ah di atas menunjukkan bahwa konflik Syi'ah di Sampang Madura adalah konflik berkepanjangan yang diawali sejak tahun 2004. Meski demikian, apa persisnya yang menyebabkan konflik tersebut masih menjadi perdebatan. Ada yang menyebutkan bahwa konflik tersebut bukan konflik keagamaaan seperti ditudingkan banyak pihak. Konflik tersebut hanya dilatari oleh perselisihan keluarga antara Tajul Muluk dan adiknya Raisul Hukama. Bahkan ada yang mengatakan konflik berdarah itu disebabkan oleh faktor asmara dengan Tajul Muluk, Raisul Hukama, dan Halima sebagai tokoh kunci.

Faktor keluarga sebagai pemicu ini diamini Ketua Umum PBNU, Said Aqil Siraj. Aqil mengatakan bahwa konflik Sampang bukan konflik antara Sunni-Syi'ah melainkan konflik keluarga. Konflik keluarga ini bisa dipicu oleh berbagai persoalan, termasuk masalah perebutan pengaruh, santri, pesantren ataupun wakaf. Buktinya, di Jawa Barat dan Jawa Tengah tidak terjadi konflik seperti di Sampang. ${ }^{25}$ Faidhol Mubarak, Direktur Ahlussunnah wal al-Jamaah (Aswaja) PCNU Kabupaten Sampang, konflik keluarga dipicu oleh Tajul Muluk yang keluar dari kesepakatan semula karena menyelipkan nadanada provokasi dalam dakwahnya. ${ }^{26}$

Menteri Agama, Suryadarma Ali, juga mengungkapkan bahwa akar persoalan perselisihan kaum Sunni-Syi'ah di Sampang adalah konflik keluarga antara Tajul Muluk dan Raisul Hukama bukan konflik keagamaan. Konflik keluarga tersebut berlangsung berlarut-larut sehingga melibatkan penganut dari dua kelompok, yaitu kelompok Tajul Muluk dan kelompok

25 Anang, http://www.republika.co.id/ diakses tanggal 23 Januari 2019.

26 NU Online, "Tidak Ada Konflik Sunni-Syi'ah di Sampang". http://www.nu.or.id/a,public-m,dinamic-s,pdf-ids, 1-id,35653-lang,id-c,warta. Volume 30 Nomor 1 Januari-Juni 2019 
Raisul Hukama. ${ }^{27}$ Ummah, ibu Tajul Muluk dan Raisul Hukama, membenarkan ada konflik pribadi antara keduanya tidak terselesaikan secara tuntas. ${ }^{28}$ Sejak saat itu pula dan sampai saat ini, konflik Sunni Syia'ah Sampang Madura belum menemukan titik terang penyelesaiannya. Jalan resolusi konflik, seolah tidak mungkin terbuka bagi kedua aliran kepaercayaan tersebut.

\section{Anak-Anak Komunitas Syiah Sampang Madura}

Anak-anak komunitas Syiah Sampang Madura adalah anakanak korban pertarungan pemahaman keagamaan orang tuanya. Sebagian besar, mereka masih usia 5 sampai 13 tahun. Sedangkan anak usia 13 tahun sampai 18 tahun berada di lingkungan pondok pesantren. Pada anak-anak usia 13 tahun ke atas, mereka tidak merasakan langsung konflik yang manifes. Hal membuat tingkat kecerdasan dalam memahami materi pembelajaran juga sangat berbeda.

Anak-anak Komunitas Syiah Sampang ketika di Madura mengikuti kegiatan belajar mengajar di Sekolah Dasar (SD) Negeri Karang Gayam 4. Selama kegiaan belajar mengajar, mereka sudah mendapat stigma negatif oleh guru dan temanteman mereka sebagai penganut faham Syia'ah yang dinilai sesat dan menyesatkan. Mereka tidak mendapatkan fasilitas pendidikan secara maksimal. Saat pelajaran agama Islam mereka selalu menjadi objek bullying.

Secara umum, sejatinya penduduk Desa Nangkrenang, Desa Karang Gayam, Kecamatan Omben , Kabupaten Sampang tidak

27 Tempo, "Menteri Agama: Konflik Sampang Masalah Keluarga", dalam http://www.tempo.co/read/news/2012/08/28/058425931/MenteriAgama-Konflik Sampang-Masalah-Keluarga. Diakses tanggal 24 Januari 2019.

28 Okezone.com, “Asal Mula Konflik Sampang Versi Ibunda Tajul Muluk-Rois", dalam http://news.okezone.com/read/2012/08/30/337/682477/redirect diakses tanggal24 Januari 2019. 
memiliki perhatian besar terhadap pendidikan, terlebih pendidikan umum. Anak-anak pasca menyelesaikan sekolah dasar (SD) atau Madrasah Ibtidaiyah (MI) selalu dikirim ke pondok-pondok pesantren, termasuk anak-anak komunitas Syi'ah. Hal ini dapat dipahami, bangunan kesadaran anak adalah homogen, tidak terlalu banyak melihat perbedaan. Hasilnya mereka cenderung menutup diri terhadap yang berbeda jika perbedaan itu disampaikan oleh pemuka agama masing-masing. meskipun demikian, anak-anak pengungsi Syiah mempunyai kesamaan perkembangan dengan anak-anak yang lain.

Anak-anak komunitas Syiah yang mengikuti pendidikan damai mempunyai ciri-ciri perkembangan sebagai berikut:

1. Konkret

Konkret mengandung makna proses belajar beranjak dari hal-hal yang konkrt yakni yang dapat dilihat, didengar, dibaui, diraba, dan diotak atik, dengan titik penekanan pada pemanfaatan lingkungan sebagai sumber belajar. Pemanfaatan lingkungan akan menghasilkan proses dan hasil belajar yang lebih bermakna dan bernilai, sebab siswa dihadapkan dengan peristiwa dan keadaan yang sebenarnya, keadaan yang alami, sehingga lebih nyata, lebih faktual, lebih bermakna, dan kebenarannya lebih dapat dipertanggungjawabkan.

\section{Integratif}

Pada tahap usia sekolah dasar anak memandang sesuatu yang dipelajari sebagai suatu keutuhan, mereka belum mampu memilah-milah konsep dari berbagai disiplin ilmu, hal ini melukiskan cara berpikir anak yang deduktif yakni dari hal umum kebagian demi bagian.

\section{Hierarkis}

Pada tahapan usia sekolah dasar, cara anak belajar berkembang secara bertahap mulai dari hal-hal yang sederhana ke hal-hal yang lebih kompleks. Sehubungan dengan hal tersebut, maka perlu diperhatikan mengenai urutan logis, 
keterkaitan antar materi, dan cakupan keluasan serta kedalaman materi. ${ }^{29}$

Betapapun demikian, kelemahan mendasar anak-anak komunitas Syiah Sampang Madura mempunyai kesadaran warisan balas dendam terhadap sepa saja yang terlibat mengusir kelompok mereka. Hal ini karena diwariskan oleh orang tua atau pun pemuk agama mereka. Rohil, salah satu anak korban yang terbunuh saat pengusiran selalu merasa ingin membalas perlakukan orang-oarang yang menghabisi bapaknya. Rohil selalu diberitahu oleh ibunya tentang siapa yang menyebabkan bapaknya meninggal.

Senda dengan Rohil, Amirul juga mempunyai rasa dendam yang sangat besar terhadap orang-orang yang menyerang dan mengusir kounitas Syiah. Amirul sering mengucapkan, saya tidak takut terhadap mereka. Saat saya besar, saya cari dan saya ajak carok. Begitu besar rasa dendam tersebut, karena Amirul selalu ditunjukkan baju berdarah milik bapaknya yang dipakai saat duel dengan para pengusir. Mereka berdua sudah tidak bisa ditawar lagi.

Berdasarkan fenomena tersebut, CMARs dan Akar Teki mempunyai program pendampingan melalui psikiater. Awalnya, hal ini dilakukan sebagai sarana untuk mengetahui minat belajar dan menyelesaikan trauma anak-anak. Faktanya, guru-guru yang menjadi psikiater justru menjadi orang tua kedua bagi anak-anak pengungsi. Anak-anak merasa mendapatkan kasih sayang dan merasa dilindungi. Mereka pun lebih senang berada di kelaskelas pendidikan damai dari pada mengukiti kegiatan belajar mengajar yang diselenggarakan oleh pemerintah Jawa Timur.

\footnotetext{
${ }^{29}$ Sonodji,"Pembelajaran Tematik" dalam http://www.ditnagadikti.org/ditnaga/files/PIP/tematiik diakses 24 Januari 2019. 
Pendidikan Damai... Oleh: Yasin Nurfalah

Konsep Pendidikan Damai Pada Anak-Anak Komunitas Syiah Sampang Madura

Pendidikan damai untuk anak-anak komunitas Syiah Sampang Madura di pengungsian mempunyai konsep satau wajah atau "one demension". Semua mata pelajaran digunakan sebagai sarana menginfiltrasi peahaman-pemahaman nilai-nilai kebangsaan Indonesia. Contoh-comtoh yang digunakan adalah bertema-tema keberagaamaan.

Rancang bangun untuk melaksanakan pendidikan damai disusun sebagai berikut:

a. Reformasi Kurikulum. Dalam hal ini, kurikulum nasional hanya sebagai acuan menetepkan kompetensi dasar anak. Akan tetapi lebih ditekankan pada kebutuhan anak dengan melihat kondisi psikologis anak. Contoh, kompetensi dasar membaca menulis dan menghitung pada anak kelas bawah. Maka yang diajarkan mengeja nama-nama lambang negara, dasar negara, lambang Negara Indonesia dan simbol-simbol kebesaran bangsa Indonesia. Sedangkan proses pembelajaran menghitung mengunakan simbol-simbol keanekaragaman suku, bahasa dan kekayaan Bangsa Indonesia.

b. Mengajarkan prinsip-prinsip keadilan sosial, kesetaraan dan pemenuhan hak-hak dasar manusia. Dalam hal ini, materi yang diajarkan lebih banyak menggunakan metode metode mastery and fun learning. Artinya, proses pembelajaran ditekankan pada penguasaan peserta didik atas materi ajar. Metode ini dipadu dengan berbagai permainan yang menyenangkan dan edukatif.

c. Pendidikan Kesabaran, Toleransi. Kesetaraan gender dan pembauran dengan masyarakat umum. Pada awalnya, menurut anak pengungsi memiliki watak keras. Ketika tersinggung, kata-kata seperti “aku bunuh kamu, aku carok kamu” terbiasa keluar. Ketika marah mereka juga 
langsung mengambil batu, mengancam untuk melempar siapa saja yang membuat mereka marah. Menurut CMARs, mendidik atau bercanda dengan anak-anak pengungsi harus menghindarkan menghina martabat mereka atau pilihan membela jamaah Syi'ah milik Ust. Tajul Muluk. Sedangkan, untuk menghilangkan stereotype anak-anak pengungsi, maka mereka diajarkan untuk berbaur dengan masyarakat. Tidak jarang mereka diperbantukan untuk membantu masyarakat yang memilik acara kerja bakti antar tetangga di rumah susun, diajak rekreasi ke tempat wisata dan berbaur dengan pengunjung yang lain. Dengan cara ini, tidak sedikit masayarakat yang menaruh simpati dan menyisihkan sebagian rezeki mereka, baik berupa makanan maupun uang untuk disumbangkan kepada anak-anak korban konflik tersebut.

d. Pendidikan Life Skills dan Pengembangan Bakat Minat CMARs menyadari bahwa anak-anak korban konflik ini tidak akan selamanya diurus oleh lembaga pendamping, mereka harus bisa hidup mandiri di masa yang akan datang. Maka mereka juga diajari beberapa kecakapan yang membuat mereka siap untuk hidup mandiri. Misalnya mengembangkan kemampuan bernyanyi atau melukis, pengembangan beternak ayam dan ikan, dan lain sebagainya. ${ }^{30}$

Klasifikasi tersebut, pada intinya dapat menunjukkan indikator yang jelas. Indikator dalam pendidikan yang mampu memanusiakan manusia sesuai dengan hak yang melekat padanya. Di samping itu, pendidikan yang memberikan pengakuan sepenuhnya atas keberbedaan dirinya dengan

${ }^{30}$ Ahmad Zainul Hamdi, "Titik Nol Jaminan Kebebasan Beraga dan Berkeyakinan (KBB) Bagi Jama'aSyiah Sampang Madura”, Annual Report, (Surabaya: CMARs, 2014), Naskah Hasil Press Realese Laporan Tahunan LBH Surabaya, h 176. 
komponen pluralitas yang menyangkut aspek etnis, budaya, agama, keyakinan, suku, dan peradaban. Jadi dapat dipahami bahwa untuk merancang pendidikan damai, yakni melakukan reformasi kurikulum, mengajarkan prinsip-prinsip keadilan sosial, mengembangkan kompetensi kurikulum dan melaksanakan pedagogik kesataraan (equality pedagogy).

Mengacu kepada konsep pendidikan damai, maka program pembelajaran yang dikembangkan harus memiliki kesesuaian dengan kebutuhan pebelajar dan kondisi sosial. Model pembelajaran pendidikan damai yang dikembangkan diarahkan pada beberapa kompetensi dasar. Pertama, mengembangkan kompetensi akademik standar dan dasar (standad and basic academic skills) tentang nilai persatuan dan kesatuan, demokrasi, keadilan, kebebasan, persamaan derajat atau saling menghargai dalam beraneka jenis keberagaman. Kedua, mengembangkan kompetensi sosial agar dapat menumbuhkan pemahaman yang lebih baik (a better understanding) tentang latar belakang budaya dan agama sendiri dan juga budaya dan agama lain dalam masyarakat. Ketiga, mengembangkan kompetensi akademik untuk menganalisis dan membuat keputusan yang cerdas (intelegent dicisions) tentang isu-isu dan masalah keseharian (real life problems) melalui sebuah proses demokratis atau penyelidikan dialogis (dialogical inquiry). Keempat, membantu mengkonseptualisasi dan mengaspirasikan konstruksi masyarakat yang lebih baik, demokratis, egaliter, tanpa ada diskriminasi, penindasan, dan pelanggaran terhadap nilai asasi universal. ${ }^{31}$

Nilai-nilai yang hendak ditanamkan terhadap peserta didik adalah nasionalisme dan pluralisme. Kedua nilai ini akan dibentuk berdasarkan budaya dan pengalaman hidup yang mereka miliki.

31 A. Khoirul Mustamir, "Dokumen Annual Repoort Program Pendampingan Anak Pengungsi Syi'ah" (Surabaya: CMARS, 2014), h. 17. 


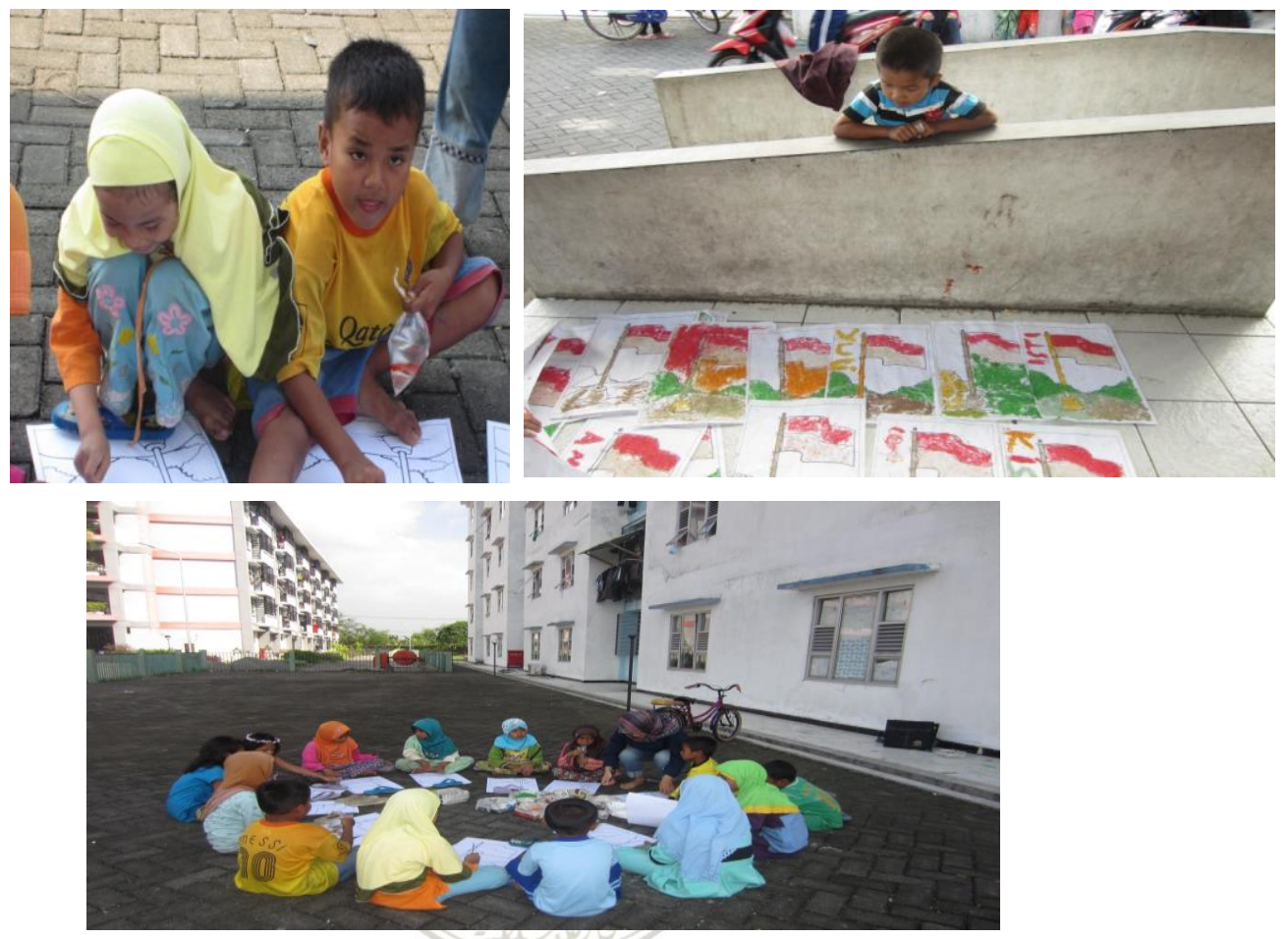

Hasil Pendidikan Damai Pada Anak-Anak Komunitas Syiah Sampang Madura

Secara umum, hasil pendidikan damai anak-anak pengungsi Syiah Sampang Madura belum menunjukkan hasil maksimal. Pasalnya, kesadaran perlunya pendidikan kurang mendapat dukungan dari orang tua dan pemuka agama Syi'ah. Dari 76 anak pengungsi yang setiap hari hadir untuk mengikuti kegiatan pendidikan damai hanya 40-45. Untuk lebih detailnya berikut, peneliti menyuguhkan hasil setiap bagian kegiatan pembeljaran:

\section{Tahap pertama}

Langkah awal program ini adalah identifikasi masalah, yaitu mengumpulkan data korban anak-anak yang meliputi usia, jenis kelamin, kondisi fisik, dan kondisi keluarganya melalui 
survei lapangan atau wawancara kepada anak-anak pengungsi: Hasil telaah pada tahap ini, masih banyak anak-anak yang tidak mempunyai kesadaran untuk mengikuti kegiatan pendidikan damai. Alasan paling banyak adalah tidak mendapatkan dukungan dari orang tua. Saat mereka belajar harus membantu orang tua mencari reziki di Pasar Puspa Agro, Jemundo Sidoarjo.

2. Tahap kedua

Melakukan spesifikasi masalah. Setelah data terkumpul maka anak-anak pemgungsi dikelompokkan menjadi beberapa kelompok sesuai kriteria-kriteria dari masing-masing anak yang memiliki kurang lebih kriteria yang sama ataupun mirip. Hasilnya didapatkan semua anak mempunyai kekuarangan dalam mengeja, membaca kalimat bahasa Indonesia dengan baik dan benar. Mereka mempunyai kecakapan dalam perdagangan (menghitung laba dan rugi). Betapapun demikian, anak-anak sangat kurang dalam memahami matematika dasar. Hal ini juga mengakibatkan sulitnya materi matematika dipahami anak-anak pengungsi.

3. Tahap Ketiga

Setelah identifikasi dan spesifikasi masalah, tahap ketiga adalah penanganan trauma disesuaikan dengan permasalahan yang dimiliki anak. Penanganan ini memiliki empat titik poin dalam pencarian solusi masalah trauma, yaitu fisik, emosional, intelektual dan spiritual. Karena keempat titik poin tersebut merupakan prinsip keseimbangan dalam hidup manusia.

Hasilnya, pendidikan damai ini mampu mengatasi trauma. Misalnya dengan pelatihan bagaimana mengatasi trauma sesuai umur atau jenjang pendidikan anak. Anak yang sudah mengenyam pendidikan, biasanya mudah melupakan traumanya melalui berbagai permainan olah fisik ataupun memancing pemikiran-pemikiran sederhana, metode "bermain" seperti metode tebak-tebakan, sulap ataupun olah kreasi dari bahan 
sekitar. Sedangkan anak-anak balita akan lebih menyukai bermain mobil-mobilan yang tinggal pakai agak rusak pun tak mengapa, bermain pembayangan, asal gambar dan pantomim yang lucu-lucu serta sekedar mendengar dongeng lucu tentang binatang ataupun tumbuhan serta kehidupan yang belum pernah mereka lihat.

Berdasarkan tahapan tahapan dan pelaksanaan pendidikan damai, saat ini anak-anak mempunyai kesadaran untuk belajar atau masuk sekolah-sekolah yang ada di sekeliling tempat pengungsian. Anak-anak tidak lagi mersa takut bertemu dengan anak-anak di luar komunitas mereka.

\section{Penutup}

Berdasarkan kajian di atas, secara umum, konflik berlatar belakang agama sangat sulit untuk ditemukan jalan rekonsiliasi. Praktik-praktik budaya lokal Madura seperti carok pun tidak mampu menyelesaikan, meskipun banyak penelitian yang menegaskan carok terjadi tidak mungkin berlatar belakang agama. Dalam situasi tersebut, kerugian pun dirasakan banyak orang yang terlibat pasca konflik, termasuk pemangku kewajiban yaitu negara. Anak-anak selalu menjadi korban tanpa pernah ada yang mampu mendengar suaranya. Oleh karena itu, CMARs dan Akar Teki membuat program "Pendidikan Damai" bagi anak-anak pengungsi Syiah Sampang Madura di Rumah Susun (Rusun Nawa) Puspa Agro, Jemundo Sidoarjo. Selama pelaksanaan program tersebut dapat disimpulkan:

1. Pendidikan damai sangat tepat digunakan untuk pendidikan anak-anak pengungsi Syiah Sampang Madura. Langkah yang harus ditempuh adalah melakukan reformasi kurikulum didasarkan pada kebutuhan anak-anak pengungsi. Strategi yang paling baik adalah pendidikan dan bermain (metode mastery and fun learning). Artinya, proses pembelajaran ditekankan pada penguasaan peserta didik atas materi ajar. 
Pendidikan Damai... Oleh: Tasin Nurfalah

Metode ini dipadu dengan berbagai permainan yang menyenangkan dan edukatif.

2. Hasilnya, ada semangat perubahan cara pandang meskipun hambatan utama dari keluarga dan tokoh pimpinan Jamaah Syiah Sampang Madura. Komunitas ini masih menganggap rendah materi-materi sekolah umum, sehingga prioritas sekolah agama. Akibatnya, tokoh agama (pimpinan jamaah Syiah) menjadi sumber satu-satunya ilmu pengetahuan. 
Adam Kuper da Jessica Kuper, Ensiklopedi Ilmu-ilmu Sosial, Haris Munandar (Penerjemah), (Jakarta: RajaGrafindo Persada, 2000)

Ahmad Baedowi, "Pendidikan Damai dan Resolusi Konflik untuk Sekolah," Media Indonesia,Senin, 1 Maret2010, diundu pada 24 Januari 2019

Ahmad. D. Marimba," Pengantar Filsafat Pendidikan Islam”, (Bandung: al-Ma'arif, 1989)

Dean G. Pruit dan Jeffrey Z. Rubin, Teori Konflik Sosial, Helly P. Soetjipto (Penerjemah) Cet. III, (Yogyakarta: Pustaka Pelajar, 2011)

Harris, I. "Conceptual Underpinnings of Peace Education," in: G. Salomon \& B. Nevo(Eds) Peace Education: The Concept, Principles, and Practices around The World, Lawrence Erlbaum,(New York2000) p. 20, terj. SN. Karikasari, dkk., (Jakarta: Gramedia, 2001).

Kovenn Ekonomi Sosial dan Budaya, Ratifikasi Undang-Undng No,. 11 tahun 2005

Khoirul Mustamir, Ahmad, Dokumen Pengajuan Program Pendampingan Anak Pengungsi Syi'ah 2013 (Surabaya: CMARS, Gubeng Kertajaya) .

Muhadjir, N. "Metode Penelitian Kualitatif”.(Yogyakarta: Rake Sarasin, 2013)

Malik, Ichsan, "Kedamaian, Keadilan, Hak Asasi \& Penegakan Hukum,"'(Semarang: IAIN Walisongo, 2008)

Nazir, M. “Metode Penelitian”(Jakarta: Ghalia Indonesia, 1999)

Ngalim Purwanto, "Ilmu Pendidikan Teoritis dan Praktis", (Bandung: Remaja Rosdakarya,1995)

Tom Campbell, Tujuh Teori Sosial, Sketsa, Penilaian dan Perbandingan, F. Budi Hadiman (Penerjemah), (Yogyakarta: Kanisius, 2001) Cetakan ke-6 
Pendidikan Damai... Oleh: Yasin Nurfalah

Undang-Undang Dasar (UUD) 1945 Amandemen 4

UU No. 20 Tahun 2003 tentang Sistem Pendidikan Nasional, pasal 1 ayat 1

Wulandari, "Taat."Menciptakan Perdamaian Melalui Pendidikan Perdamaian di Sekolah." (Artikel dari MOZAIK Volume V No. 1 Januari 2015),

Zainul Hamdi, Ahmad "Titik Nol Jaminan Kebebasan Beraga dan Berkeyakinan (KBB) Bagi Jama'aSyiah Sampang Madura, Annual Report," (Surabaya: CMARs, 2014), Naskah hasil press realese Laporan Tahunan LBH Surabaya

Zainul Hamdi, Ahmad Pergeseran Islam Madura (Perjumpaan Islam Tradisional dan dan Islamisme di Bangkalan Madura Pasca Reformasi. (Suarabaya: UINSA, 2015)

Zainul Hamdi, Ahmad Titik Nol Jaminan Kebebasan Beraga dan Berkeyakinan (KBB) Bagi Jama'aSyiah Sampang Madura, Annual Report, (Surabaya: CMARs, 2015), Naskah hasil press realese Laporan Tahunan LBH Surabaya,

Zamroni. "Peace Education, Volume I, II, dan III”.(Yogyakarta, Pascasarjana UNY.2008)

Zed, M'"Metodologi Penelitian Kepustakaan."(Jakarta: Yayasan Obor Indonesia.2008)

\section{Internet:}

Anang, Http://www.republika.co.id/ Diakses tanggal 23 Januari 2019

Johan Galtung, "A Mini Theory of Peace," January 4, 2007, artikel online: http://www.transnational.org/Resources_Treasures/200 7/Galtung_MiniTheory.html,diunduh tanggal 23 Januari 2018 
Simon Fisher et.al.,Mengelola KonflikKeterampilan dan Strategi untuk Bertindak, terj. SN. Karikasari, dkk., (Jakarta: Gramedia, 2001)

Nizar, M, "Pendidikan Anak Korban Konflik," artikel online:http://pendidikanlayanankhusus.wordpress.com,, diakses 23 Januari September 2019.

NU Online, Tidak Ada Konflik Sunni-Syi'ah di Sampang.Lihat dalam www.nu.or.id/a,public-m,dinamic-s,pdf-ids, 1id,35653-lang,id-c,warta-t,... Diakses Tanggal. 23 Januari 2019

Tempo, Menteri Agama: Konflik Sampang Masalah Keluarga, lihat dalam http://www.tempo.co/read/news/2012/08/28/05842593 1/Menteri-Agama-Konflik on Sampang-MasalahKeluarga. Diakses tanggal 23 Januari 2019.

Okezone.com, Asal Mula Konflik Sampang Versi Ibunda Tajul Muluk-Rois, dalam http://news.okezone.com/read/2012/08/30/337/682477/ redirect.Diakses tanggal 23 Januari 2019.

Sonodji "Pembelajaran Tematik" dalam http://www.ditnagadikti.org/ditnaga/files/PIP/ tematiik diaksis 24 Januari 2019. 